\title{
Adolescent Psychological Well-Being: The Case of Filipino Catholic High School Students with Absentee Parents
}

\author{
Cecilia M. Sablaon ${ }^{1}$ and Dennis V. Madrigal ${ }^{2}$ \\ ${ }^{1}$ St. Therese's High School, Inc., Anini-y, Antique, Philippines \\ ${ }^{2}$ University of Negros Occidental-Recoletos, Bacolod City, Philippines
}

\begin{abstract}
Article history:
Submitted: 26 November 2020

Revised: 20 March 2021

Accepted: 25 March 2021
\end{abstract}

\section{Keywords:}

Guidance and counseling

Psychological well-being

High school students

Absentee parents

Descriptive-correlational

Catholic school

Antique

ABSTRACT. Psychological well-being (PWB) refers to a person's quality of looking at things and situations. Despite one's limitations, he/she can overcome challenges and live a satisfying, productive, and happy life. This descriptive-correlational research design assessed the level of psychological well-being of Catholic high school students with absentee parents of a private school in Antique, Philippines, during the school year 2019-2020. Selected using stratified random sampling, there were 85 respondents who participated in the study. The data were collected using Ryff's item Psychological Well-Being Scale test. Mean, standard deviations, and Spearman rank correlation were used to analyze the data. The findings of the study showed that the level of psychological well-being of Filipino Catholic high school students with absentee parents of a private school in Antique was high. Categories on personal growth, positive relations, and purpose in life were also high, while autonomy, environmental mastery, and self-acceptance were moderate. In addition, a significant relationship was found between family monthly income, academic level, and involvement in Church ministry and PWB. Meanwhile, sex and attendance on Sunday masses had no significant relationship with PWB. Thus, Catholic students demonstrated a positive view of life and cope with challenges despite the absence of their parents.

\subsection{Introduction}

Psychological well-being is about life going and being well. It is the combination of feeling and looking good and yet, functioning effectively (Huppert \& So, 2013 cited in Ruggeri et al., 2020). However, sustainable well-being does not mean feeling good always. The experience of hurting emotions like disappointment and grief is a normal part of life. Managing these painful emotions to develop potential, control life, find a sense of purpose, experience positive relationships, and stay happy (Datu \& Valdez, 2012) is essential for long-term well-being (Huppert, 2009 cited in Ruggeri et al., 2020). Living a happy life and the feeling of success and satisfaction become a predictor of positive psychological outcomes (Parks et al., 2012).

Behind a successful and happy life of any child is a strong parent-child relationship (Allen et al., 2018). However, current family structures have changed dramatically. Separation from one or both parents due to increased divorce rates, massive- scale labor migration in many areas of the world leading to a large number of children left in the home with the absence of parental cares (Tomsa \& Jenaro, 2015 cited in Fu et al., 2017) is affecting family well-being. Data reveal that in the United States, nearly four percent or three million children live at home with no parents (Vandivere et al., 2012; U.S. Census Bureau, 2018).

In addition, more than forty percent of these left-behind children are found in rural South Africa, thirty-six percent in Ecuador, more than a third of sixty-one million of all children in rural China, and twenty-seven percent of children in the Philippines (Fellmeth et al., 2018). Added to this growing concern is the feminization of migration, which affected the relationship between mother and children. Mothers are believed to be the primary caretakers of children (Linonge-Fontebo \& Rabe, 2015) whose physical presence and nurturing role in the home are all important (Keizer et al., 2019). Adolescents may spend more time with friends, but mothers remain of strong importance (Keizer et al., 2019). This scenario also transforms American families with labor force participation by mothers soared from forty-seven percent in 1975 to seventy-one percent in 2017 (U.S. Bureau of Statistics, 2018).

In Indonesia and the Philippines, more women, mostly mothers, are documented as overseas workers than men, and their absence heightens children's sense of loss (Asis \& Feranil, 2020; Lam \& Yeoh, 2019), which is detrimental on the psychological well-being of children (Antia et al., 2020).

Similarly, the scenario mentioned above is a typical home situation of many of the students studying in one of the Catholic schools in Antique. On a school-based survey done last 2019, there 
are one hundred seventy-five students who responded to have absentee parents. Many of the parents, the father or the mother, or sometimes both, leave home to look for a job or a greener pasture outside, to provide for the needs and education of children. Undermining the effects of their absence, parents' sole reason for leaving is the welfare of the family.

As a result, the Catholic schools serve as the second home for these left-behind students. Also, Catholic schools become a companion and witness to whatever these students are facing and experiencing every day. Therefore, the school should provide students an environment promoting mental and emotional well-being as well as positive behavioral change (Lester \& Cross, 2015).

Previous studies in the Philippines explore the functions of positive affective states (Villavicencio \& Bernardo, 2016), positive qualities, and strong characteristics as an indicator of students' wellbeing, adaptation, and outcomes of learning (Datu et al., 2017; Datu et al., 2017; 2018; Datu et al., 2018; King \& Datu, 2017), psychological resources (Ganotice et al., 2016; Datu \& Valdez, 2016) and locus-of-hope (Bernardo et al., 2016) administered among Filipino students and non-student groups. In addition to the study are specific people with psychological outcomes such as survivors of natural disasters (Nalipay et al., 2016; 2017), women who experience violence from an intimate partner (Bernardo \& Estrellado, 2017a; 2017b), overseas Filipino workers (Bernardo et al., 2016), and peace of mind with academic motivation and achievement of Filipino high school students (Datu et al., 2017).

So far, there has been a dearth of studies on the level of psychological well-being of Catholic high school students with absentee parents of a private school (Ryff, 2017; Lampropoulou, 2018; Fomina et al., 2020). Hence, the study determined the level of their psychological well-being of Filipino Catholic high school students with absentee parents and correlated their demographics and psychological well-being. Also, the findings of the study were utilized as the basis for designing a proposed psychological wellness program for high school students of a private school.

\subsection{Framework of the Study}

This paper theorized that psychological well-being is associated with student demographics such as sex, academic level, family monthly income, involvement in ministry, and Sunday mass attendance.

The theoretical assumption was anchored on Bowlby's attachment theory (1988), specifically on the secure attachment that once established in early life, has lasting psychological effects on human development. Moreover, attachment theory emphasizes experiences with primary caregivers, which is expected to form and influence adolescents' working models of the world, thus, affecting adolescents' psychological well-being. In addition, when the secure attachment is developed, a slow process of detachment may not be difficult because the child has developed the ability to cope with environmental changes (Garcia et al., 2014) and challenges encountered at various developmental stages (Ryff, 1989). In comparison with young children who need close physical proximity and availability to experience comfort, adolescents, on the other hand, do not need the same degree of physical closeness. The feeling of comfort can be derived from knowing that their parents are supportive even if they are not present (Moretti \& Peled, 2004).

Another theory for which this study is anchored is Bronfenbrenner's ecological systems theory (Bronfenbrenner \& Morris, 1998; Bronfenbrenner \& Evans, 2000), which centers on understanding intercommunications among adolescents, the circumstances of their development, and the methods that account for their development. One of the five systems presented in this theory is the microsystem, which is made up of groups that have direct contact with the child, specifically the family. Bronfenbrenner (1977) describes a microsystem as a set of activities, social roles, and interpersonal relationships undergone by an individual in a direct setting. These influences identified as direct include the family, peer groups, and school setting (Bronfenbrenner, 1994). Ryff (2014) attested that the well-being of a child is positively linked with family role involvement.

Considering the contents of the two theories, the study finds them relevant in determining the psychological well-being of Catholic high school students with absentee parents.

\subsection{Methods}

The study aimed to assess the level of psychological well-being of Filipino Catholic high school students with absentee parents of a private school in Antique, Philippines. The researcher used the descriptive-correlational research design describing the level of psychological well-being of the student-respondents and determining the relationship existing between psychological well-being 
and students' demographics such as sex, family monthly income, academic level, involvement in Church ministry, and Sunday mass attendance.

The respondents of the study were the Filipino Catholic junior and senior high school students with absentee parents of a private school in Antique, Philippines during the AY 2019-2020. A total of 85 Catholic students participated in the study using stratified random sampling. Sixty-five of the actual respondents were Junior high school, and 20 were Senior high school. They were identified using the lottery.

To gather the required data, the researcher used a standardized questionnaire, the Psychological Well-Being Scale Test by Ryff (1989). The instrument consisted of 42-item questions with a series of statements reflecting the six areas of psychological well-being: autonomy, environmental mastery, personal growth, positive relations with others, purpose in life, and self-acceptance. Respondents rated the statements using the 7-point scale which ranged from 1- strongly agree to 7- strongly disagree. To establish the reliability of Ryff's Psychological Well-Being scale (Ryff, 1989), the researcher pilot tested the questionnaire to 30 students of a Catholic school who were not included as actual respondents of the study. Using Cronbach's alpha, the reliability test yielded a score of 0.713 , which means that the questionnaire is reliable (Pallant, 2020).

The approval of the school principal of the private Catholic high school was obtained before the execution of the study. The respondents were informed about the purpose and direction, and scope of the study, the nature, and components of the questionnaire, most notably, the confirmation of their willingness to engage in the study. Parental assent was also secured. A licensed guidance counselor assisted the researcher in the conduct of the test. At the same time, the researcher retrieved the survey questionnaire, tabulated, and submitted the data for statistical treatment.

The descriptive and correlational data analyses were utilized in the analysis of data with the aid of appropriate statistical tools. The descriptive analysis was used to assess the level of psychological well-being of students using Mean and Standard Deviation. On the other hand, a correlational analysis was employed to establish the relationship between psychological well-being and students' demographics. Using Kolmogorov-Smirnov and Shapiro Wilk test, the results showed that variables autonomy [KS=0.146, $p=0.000$, environmental mastery [KS=0.120, $p=0.004$ ], personal growth $[K S=0.152, p=0.000]$, positive relation $[K S=0.068, p=0.20]$, purpose in life $[K S=0.081, p=0.020$ ], self-acceptance $[K S=0.124, p=0.003]$, and psychological well-being $[K S=0.097, p=0.048]$, were not normally distributed. Hence, the use of the Spearman rank correlation for statistical treatment for the data of inferential problems was appropriate.

\subsection{Results and Discussion}

\section{Profile of the respondents}

Table 2 presents the demographic profile of 85 Filipino Catholic high school students with absentee parents in a Catholic High School in the province of Antique during the school year 20192020. They were profiled according to sex, family monthly income, academic level, involvement in ministry, and Sunday mass attendance.

Overall, the majority of the respondents were junior high school students ( $f=65,76.5 \%)$. When further categorized according to variables, there were more female respondents ( $f=48,56.5 \%$ ) but quite not far from males. Most belonged to low family monthly income ( $f=64,75.3 \%$, more involvement in ministry $(f=55,64.7 \%)$, and non-attendance every Sunday mass ( $f=76,89.4 \%)$ had the biggest number of respondents.

The demographics signify that many of the students with absentee parents belonged to the low family monthly income category. Although most were involved in Church ministry, the data showed that they do not attend mass every Sunday. 
Table 2. Profile of the Filipino Catholic high school students

\begin{tabular}{lcc}
\hline \multicolumn{1}{c}{ Variable } & f & $\%$ \\
\hline Sex & & \\
Male & 37 & 43.5 \\
Female & 48 & 56.5 \\
Family Monthly Income & & \\
Low & 64 & 75.3 \\
High & 21 & 24.7 \\
Academic Level & & \\
Junior High & 65 & 76.5 \\
Senior High & 20 & 23.5 \\
Involvement in Ministry & & \\
Yes & 55 & 64.7 \\
No & 30 & 35.3 \\
Sunday Mass Attendance & & \\
Yes & 9 & 10.6 \\
No & 76 & 89.4 \\
Total & 85 & 100.0 \\
\hline
\end{tabular}

Level of psychological well-being of Filipino Catholic high school students with absentee parents

The level of psychological well-being of Filipino Catholic high school students refers to one's ability to cope with life's challenges. It is a person's quality of looking at things and situations that despite one's limitations, he/she can overcome challenges and live a satisfying, productive, and happy life.

Generally, the findings in Tables $3 \mathrm{~A}$ and $3 \mathrm{~B}$ showed that the level of psychological well-being of high school students is high $(M=4.50, S D=0.43)$. In terms of the six categories of psychological wellbeing, personal growth $(M=4.73, S D=0.81)$, positive relations $(M=4.89, S D=0.76)$, and purpose in life $(M=4.59, S D=0.74)$ scored high. On the other hand, autonomy $(M=4.21, S D=0.54)$, environmental mastery $(M=4.18, S D=0.60)$, and self-acceptance $(M=4.39, S D=0.68)$ were on the average level.

Table $3 A$. Level of psychological well-being

\begin{tabular}{|c|c|c|c|c|c|c|c|c|c|c|c|c|}
\hline \multirow[t]{2}{*}{ Variable } & \multicolumn{2}{|c|}{$\begin{array}{l}\text { Psychological } \\
\text { Well-being }\end{array}$} & \multirow[b]{2}{*}{ Int } & \multicolumn{3}{|c|}{ Autonomy } & \multicolumn{3}{|c|}{$\begin{array}{l}\text { Environmental } \\
\text { Mastery }\end{array}$} & \multicolumn{3}{|c|}{ Personal Growth } \\
\hline & $M$ & SD & & M & SD & Int & M & SD & Int & $M$ & SD & Int \\
\hline \multicolumn{13}{|l|}{ Sex } \\
\hline Male & 4.500 & 0.44 & $\mathrm{Hi}$ & 4.24 & 0.55 & Av & 4.20 & 0.58 & Av & 4.61 & 0.88 & $\mathrm{Hi}$ \\
\hline Female & 4.49 & 0.42 & $\mathrm{Hi}$ & 4.18 & 0.54 & Av & 4.17 & 0.62 & Av & 4.82 & 0.75 & $\mathrm{Hi}$ \\
\hline \multicolumn{13}{|c|}{ Family Monthly Income } \\
\hline Low & 4.48 & 0.44 & $\mathrm{Hi}$ & 4.18 & 0.55 & $\mathrm{Av}$ & 4.23 & 0.60 & Av & 4.71 & 0.83 & $\mathrm{Hi}$ \\
\hline High & 4.55 & 0.39 & $\mathrm{Hi}$ & 4.28 & 0.54 & Av & 4.03 & 0.57 & Av & 4.78 & 0.77 & $\mathrm{Hi}$ \\
\hline \multicolumn{13}{|c|}{ Academic Level } \\
\hline JHS & 4.43 & 0.39 & Av & 4.23 & 0.55 & $\mathrm{Av}$ & 4.16 & 0.59 & Av & 4.60 & 0.77 & $\mathrm{Hi}$ \\
\hline SHS & 4.72 & 0.48 & $\mathrm{Hi}$ & 4.11 & 0.54 & Av & 4.27 & 0.62 & Av & 5.15 & 0.79 & $\mathrm{Hi}$ \\
\hline \multicolumn{13}{|c|}{ Involvement in Ministry } \\
\hline Yes & 4.57 & 0.47 & $\mathrm{Hi}$ & 4.17 & 0.48 & $\mathrm{Av}$ & 4.18 & 0.62 & Av & 4.91 & 0.87 & $\mathrm{Hi}$ \\
\hline No & 4.36 & 0.30 & Av & 4.28 & 0.65 & Av & 4.18 & 0.56 & Av & 4.39 & 0.56 & $A v$ \\
\hline \multicolumn{13}{|c|}{ Suncay Mass Attendance } \\
\hline Yes & 4.31 & 0.36 & Av & 4.10 & 0.52 & Av & 4.17 & 0.74 & Av & 4.25 & 0.88 & Av \\
\hline No & 4.52 & 0.43 & $\mathrm{Hi}$ & 4.22 & 0.55 & $A v$ & 4.18 & 0.58 & Av & 4.78 & 0.79 & $\mathrm{Hi}$ \\
\hline As a Whole & 4.50 & 0.43 & $\mathrm{Hi}$ & 4.21 & 0.54 & Av & 4.18 & 0.60 & Av & 4.73 & 0.81 & $\mathrm{Hi}$ \\
\hline
\end{tabular}




\begin{tabular}{|c|c|c|c|c|c|c|c|c|c|c|c|c|}
\hline \multirow[t]{2}{*}{ Variable } & \multicolumn{2}{|c|}{$\begin{array}{l}\text { Psychological } \\
\text { Well-being }\end{array}$} & \multirow[b]{2}{*}{ Int } & \multicolumn{3}{|c|}{$\begin{array}{l}\text { Positive } \\
\text { Relations }\end{array}$} & \multicolumn{3}{|c|}{ Purpose in Life } & \multicolumn{3}{|c|}{ Self-acceptance } \\
\hline & $\mathrm{M}$ & SD & & M & SD & Int & $M$ & SD & Int & $M$ & SD & Int \\
\hline \multicolumn{13}{|l|}{ Sex } \\
\hline Male & 4.500 & 0.44 & $\mathrm{Hi}$ & 4.90 & 0.86 & $\mathrm{Hi}$ & 4.53 & 0.67 & $\mathrm{Hi}$ & 4.52 & 0.60 & $\mathrm{Hi}$ \\
\hline Female & 4.49 & 0.42 & $\mathrm{Hi}$ & 4.88 & 0.69 & $\mathrm{Hi}$ & 4.63 & 0.79 & $\mathrm{Hi}$ & 4.28 & 0.73 & Av \\
\hline \multicolumn{13}{|c|}{ Family Monthly Income } \\
\hline Low & 4.48 & 0.44 & $\mathrm{Hi}$ & 4.85 & 0.80 & $\mathrm{Hi}$ & 4.58 & 0.71 & $\mathrm{Hi}$ & 4.33 & 0.67 & $\mathrm{Av}$ \\
\hline High & 4.55 & 0.39 & $\mathrm{Hi}$ & 5.03 & 0.65 & $\mathrm{Hi}$ & 4.62 & 0.84 & $\mathrm{Hi}$ & 4.54 & 0.70 & $\mathrm{Hi}$ \\
\hline \multicolumn{13}{|c|}{ Academic Level } \\
\hline JHS & 4.43 & 0.39 & Av & 4.75 & 0.74 & $\mathrm{Hi}$ & 4.48 & 0.69 & $\mathrm{Hi}$ & 4.35 & 0.72 & Av \\
\hline SHS & 4.72 & 0.48 & $\mathrm{Hi}$ & 5.36 & 0.66 & $\mathrm{VH}$ & 4.94 & 0.82 & $\mathrm{Hi}$ & 4.51 & 0.54 & $\mathrm{Hi}$ \\
\hline \multicolumn{13}{|c|}{ Involvement in Ministry } \\
\hline Yes & 4.57 & 0.47 & $\mathrm{Hi}$ & 4.99 & 0.79 & $\mathrm{Hi}$ & 4.74 & 0.75 & $\mathrm{Hi}$ & 4.43 & 0.74 & $\mathrm{~A} v$ \\
\hline No & 4.36 & 0.30 & Av & 4.70 & 0.69 & $\mathrm{Hi}$ & 4.31 & 0.65 & Av & 4.31 & 0.56 & Av \\
\hline \multicolumn{13}{|c|}{ Sunday Mass Attendance } \\
\hline Yes & 4.31 & 0.36 & Av & 4.89 & 0.87 & $\mathrm{Hi}$ & 4.27 & 0.55 & Av & 4.17 & 0.84 & $\mathrm{Av}$ \\
\hline No & 4.52 & 0.43 & $\mathrm{Hi}$ & 4.89 & 0.76 & $\mathrm{Hi}$ & 4.62 & 0.76 & $\mathrm{Hi}$ & 4.41 & 0.66 & Av \\
\hline As a Whole & 4.50 & 0.43 & $\mathrm{Hi}$ & 4.89 & 0.76 & $\mathrm{Hi}$ & 4.59 & 0.74 & $\mathrm{Hi}$ & 4.39 & 0.68 & Av \\
\hline
\end{tabular}

Note: $\mathrm{Av}=$ Average, $\mathrm{Hi}=\mathrm{High}, \mathrm{VH}=\mathrm{Very} \mathrm{Hi}$

Interestingly, positive relations scored the highest, while environmental mastery fell on to the last of the six categories. These figures mean that Filipino Catholic high school students, even with the absence of parents, can still cope and overcome life challenges and live a good and happy life. Since they are in their adolescence and late adolescence periods, the influence of peer relationship is high. On the other hand, responsibilities become a bit difficult for them to handle and to cope with, especially when parents are not around.

When grouped according to demographics, a high level of psychological well-being was evident on sex, male and female, respectively $(M=4.50, S D=0.44 ; M=4.49, S D=0.42)$, as well as family monthly income, both low and high $(\mathrm{M}=4.48, \mathrm{SD}=0.44, \mathrm{M}=4.55, \mathrm{SD}=0.39)$. On the other hand, Junior high school $(M=4.43, S D=0.39)$, non-involvement in ministry $(M=4.36, S D=0.30)$, and those who were attending mass every Sunday $(M=4.31, S D=0.36)$ fell under an average level of psychological wellbeing. In contrast, the rest fell into the high psychological well-being category. Interestingly on the academic level, Senior high school students scored very high on positive relations $(M=5.36, S D=0.66)$ and high on self-acceptance $(M=4.51, S D=0.54)$ while Junior high school students scored high and average respectively on the same categories $(M=4.75, S D=0.74, M=4.35, S D=0.72)$. Meaning to say, as one matures in age, the ability to understand and develop a warm and satisfying relationship with others and the development of a positive attitude and understanding of oneself become great.

The findings of the study showed that the psychological well-being of the respondents is relatively high. Although if a focused analysis of the six categories was given full attention, there are observable and impressive differences in various demographics. For instance, those who belonged to high family income showed higher positive relations than those with low income. This is maybe because of the status gained from material possessions. Odgers (2015) would say that those who have less in life may feel deprived, and children of low-income families may seem to suffer when growing up around more affluent peers. Nevertheless, the results revealed that Filipino Catholic high school students studying in a private school in Antique were able to find and experience life meaningfully despite the absence of parents. The school proved that an accepting and warm school environment has a positive effect on students' well-being (Fomina et al., 2020).

\section{Relationship between sex and psychological well-being}

Spearman rank correlation was used to determine the significant relationship between sex and psychological well-being. The findings in Table 4 showed that there was no significant relationship between psychological well-being and sex $[\rho(83)=-0.010, p=0.926]$. Hence, the null hypothesis was accepted.

The findings revealed that both males and females could translate experiences in life into what is best. Both in their unique way could address experiences in life and adjust to make themselves better. Though nobody could claim uniformity or similarity in facing life, situations surrounding every individual specifically the atmosphere and the support from their Catholic school, contribute to how one reacts and interacts with these experiences. 
Some studies confirmed and supported the result of the study that using the measures of psychological well-being, men and women showed no significant difference (Suleiman et al., 2017; Cheung et al., 2016).

However, several studies on psychological well-being showed opposite results (Patalay \& Fitzsimons, 2018; Booker et al., 2018; Inchley \& Currie, 2016). They found a decrease in psychological well-being among girls than boys. In addition, Sun et al. (2016) and Akhter (2015) discovered that sex was associated with positive measures of psychological well-being.

Table 4. Relationship between sex and psychological well-being

\begin{tabular}{cccc}
\hline Variable & p & df & p \\
\hline Sex & -0.010 & 83 & 0.926 \\
\hline
\end{tabular}

Note: *the correlation is significant when $\mathrm{p} \leq 0.05$

\section{Relationship between family monthly income and psychological well-being}

The findings in Table 5 showed that there was a significant relationship between psychological well-being and family monthly income $[\rho(83)=0.235, p=0.030]$. Hence, the null hypothesis was rejected. The result found support from the findings of Teh et al. (2015) and Shamsuddin et al. (2013), who found that economic status has a significant relationship with psychological wellbeing. Also, Gariepy et al. (2017) pointed out that subjective well-being in youths relates positively to family income.

Based on the result, adolescents who both belonged to the low and high-income category showed high psychological well-being. However, the overall level of psychological well-being would say that those who belonged to high income is higher compared to those with low income. Yet, Catholic school teachings emphasize that economic status is not a hindrance to experience happiness and satisfaction in life. The supportive system of the Catholic school towards students' holistic development including psychological well-being proved to be effective in a way that opportunities for continued development are offered to all without distinction or disparity among students belonging to families with either low or high income.

Table 5. Relationship between family monthly income and psychological well-being

\begin{tabular}{cccc}
\hline Variable & $\mathbf{p}$ & $\mathbf{d f}$ & $\mathbf{p}$ \\
\hline Family Monthly Income & $0.235^{*}$ & 83 & 0.030 \\
\hline
\end{tabular}

Note: *the correlation is significant when $\mathrm{p} \leq 0.05$

\section{Relationship between academic level and psychological well-being}

The findings in Table 6 showed that there was a significant relationship between psychological well-being and academic level $[\rho(83)=0.296, p=0.006]$. Hence, the null hypothesis was rejected.

The findings were supported by Keyes (2002), saying that psychological well-being can improve and increase in age and education. Meaning to say, that as the students progress to a higher grade level, the education and formation experienced in a Catholic school influenced their capacity to face and overcome challenges with courage and to engage well in life.

However, other studies opposed the findings. Numerous of these studies described that youths had experienced a lower level of well-being as they forward through adolescence (Adkins et al., 2009; Petts, 2014). Petts (2014), said that children are primarily dependent on their parents and others for their well-being up to the time they grow mature and can govern themselves or be independent.

Table 6. Relationship between academic level and psychological well-being

\begin{tabular}{cccc}
\hline Variable & $\mathbf{p}$ & $\mathbf{d f}$ & $\mathbf{p}$ \\
\hline Academic Level & $0.296^{*}$ & 83 & 0.006 \\
\hline
\end{tabular}

Note: *the correlation is significant when $p \leq 0.05$ 


\section{Relationship between Church ministry involvement and psychological well-being}

The findings in Table 7 showed that there was a significant relationship between psychological well-being and involvement in ministry $[\rho(83)=-0.233, p=0.032]$. Hence, the null hypothesis was rejected.

The findings indicated that participation in Church ministries as one of the opportunities provided by Catholic schools for growth and formation created an avenue for students to find meaning and satisfaction in life. These ministries became a source of family support system, which may be lacking at home due to parental absence. The findings affirmed the study conducted by Michaelson et al. (2015), stating that involvement in the church where individuals live in relationship with God, humanity, and the world, can create a change in the lives of young people, including adolescents. Furthermore, Estrada et al. (2019) presented that involvement and participation in religious practices promote support, care, and connectedness. As such, participation in the Church compensates the concern and guidance of parents away from home.

Table 7. Relationship between Church ministry involvement and psychological well-being

\begin{tabular}{cccc}
\hline Variable & $\mathbf{p}$ & $\mathbf{d f}$ & $\mathbf{p}$ \\
\hline Church ministry involvement & $-0.233^{*}$ & 83 & 0.032 \\
\hline
\end{tabular}

Note: *the correlation is significant when $\mathrm{p} \leq 0.05$

\section{Relationship between Sunday mass attendance and psychological well-being}

The findings in Table 8 showed that there was no significant relationship between psychological well-being and Sunday mass attendance $[\rho(83)=0.151, p=0.168]$. Hence, the null hypothesis was accepted.

Petts (2014) stated that there is evidence describing that religious attendance is good for the youth. For instance, Nell and Rothmann (2018), in his study, found that higher levels of life satisfaction and positive affect resulted from being religious. Also, those who show high or active religious and spiritual involvement radiate a more positive outlook in life (Vishkin et al., 2019; Ramsay et al., 2019).

Contrastingly, Dew et al. (2008) cited in Petts (2014), revealed that few studies found no relationship between religious attendance and youth mental health outcomes. These findings were affirmed in the result of this study, which showed that the psychological well-being of Catholic high school students with absentee parents was not associated with Sunday mass attendance. Probably, the Catholic formation and evangelization received in school had guided and supported the psychological well-being of students with absentee parents. Although Sunday mass is a primary obligation of every Catholic, religious attendance often decreases in adolescence and young adulthood (Petts, 2014).

Table 8. Relationship between Sunday Mass attendance and psychological well-being

\begin{tabular}{cccc}
\hline Variable & P & df & p \\
\hline Sunday Mass attendance & 0.151 & 83 & 0.168 \\
\hline Note: *the correlation is significant when $p<0.05$ & &
\end{tabular}

Overall, the level of psychological well-being of catholic high school students with absentee parents of a private school in Antique was revealed to be high. Categories on personal growth, positive relations, and purpose in life were also high, while autonomy, environmental mastery, and self-acceptance were moderate. Positively the results showed that parental absence did not affect the way students view life and cope with challenges. This is in contrast with numerous studies that presented the negative implications of parental absence which caused children left behind to have poor psychological well-being (Bernardi et al., 2013; Chakombera \& Mubika, 2018). The school has positively created a home and teachers replicated the role of parents. The Catholic formation, experiences, and opportunities deepened and strengthened family ties among teachers of the school and students. Students have felt support from teachers; thus, the physical absence of parents has not significantly affected students' psychological well-being. 


\subsection{Conclusion}

The level of psychological well-being of Catholic high school students with absentee parents of a private school in Antique is high based on the six categories, namely, autonomy environmental mastery, personal growth, positive relations, purpose in life, and self-acceptance. The findings indicate that the psychological well-being of students who are studying in a Catholic school is not influenced by the absence of parents. It implies that the school has succeeded in establishing a Catholic climate of being a second home and parents for these kinds of students.

Also, the religious atmosphere and participation of high school students in different Church ministries have further strengthened and stabilized their psychological wellness. Although few responded yes to a regular Sunday Mass attendance, the spiritual ambiance of the Catholic school has influenced students to cope and overcome challenges in life in the absence of their parents.

On the other hand, the correlation that existed between psychological well-being and family monthly income, academic level, and involvement in Church ministries suggests that the school needs to organize activities that facilitate the continued and positive growth of well-being among students. Although sex and Sunday Mass attendance showed no correlation in the psychological well-being, the school should uphold and stand strong on its role and mission, which is to continue to evangelize and empower Antiqueño youth.

\section{REFERENCES}

Adkins, D. E., Wang, V., Dupre, M. E., Van den Oord, E. J. C. G., \& Elder, G. H., Jr. (2009). Structure and stress: Trajectories of depressive symptoms across adolescence and young adulthood. Social Forces, 88, 31-60. https://doi.org/10.1353/sof.0.0238

Akhter, S. (2015, July-September). Psychological well-being in the student of gender difference. The International Journal of Indian Psychology, 2(4), 153-161.

Allen, J. P., Grande, L., Tan, J., \& Loeb, E. (2018). Parent and peer predictors of change in attachment security from adolescence to adulthood. Child Development, 89(4), 1120-1132.

Antia, K., Boucsein, J., Deckert, A., Dambach, P., Račaite, J., Šurkienè, G., Jaenisch, T., Horstick, O., \& Winkler, V. (2020). Effects of international labour migration on the mental health and well-being of left-behind children: A systematic literature review. International Journal of Environmental Research and Public Health, 17(12), 4335. https://doi.org/10.3390/ ijerph17124335

Asis, M. M. \& Feranil, A. (2020). Not for adults only: Toward a child lens in migration policies in Asia. Journal on Migration and Human Security, 8(1), 68-82.

Bernardi, F., Härkönen, J., Boertien, D., Andersson Rydell, L., Bastaits, K., \& Mortelmans, D. (2013). State-of-the-art report. Effects of family forms and dynamics on children's well-being and life chances: A literature review. Families and Societies working paper series 4.

Bernardo, A. B. I., Daganzo, M. A. A., \& Ocampo, A. C. G. (2016). Abusive supervision and well-being of Filipino migrant workers in Macau: Consequences for self-esteem and heritage culture attachment. Social Indicators Research. Advance online publication. https://doi.org/10.1007/ s11205-016-1446-7.

Bernardo, A. B. I. \& Estrellado, A. F. (2017a). The well-being of Filipino women who experienced intimate partner violence: A person-centered analysis. International Journal for the Advancement of Counselling, 39, 360-376.

Bernardo, A. B. I. \& Estrellado, A. F. (2017b). Locus-of-hope and help-seeking intentions of Filipino women victims of intimate partner violence. Current Psychology, 36, 66-75.

Bernardo, A. B. I., Salanga, M. G. C., Khan, A., \& Yeung, S. S. (2016). Internal and external loci-of-hope predict the use of individual and collaborative learning strategies: Evidence from university students in four Asian cities. The Asia-Pacific Education Researcher, 25(3), 367-376.

Bronfenbrenner, U. (1977). Toward an experimental ecology of human development. American psychologist, 32(7), 513

Bronfenbrenner, U., Husen, T., \& Postlethwaite, T. N. (1994). International encyclopedia of education. Ecological models of human development, 3, 37-43.

Booker, C. L., Kelly, Y. J., \& Sacker, A. (2018). Gender differences in the associations between age trends of social media interaction and well-being among 10-15-year-olds in the UK. BMC Public Health 18, 1-12. doi: 10.1186/s12889-018-5220-4 
Bowlby, J. (1988). A secure base: Clinical applications of attachment theory. London: Tavistock.

Bronfenbrenner, U., \& Evans, G. W. (2000). Developmental science in the 21st century: Emerging questions, theoretical models, research designs and empirical findings. Social development, 9(1), 115-125.

Bronfenbrenner, U., \& Morris, P.A. (1998). The ecology of the developmental process. In Handbook of Child Psychology, Theoretical Models of Human Development, ed. W Damon, RM Lerner, 1:993-1028. New York: Wiley. 5thed.

Chakombera, P. \& Mubika, A. K. (2018) A comparative analysis on the psychological wellbeing of adolescents with parents in the Diaspora and those with parents in the home country: A case study of adolescents at Nemakonde high school, Mashonaland West Region, Zimbabwe. International Journal of Humanities Social Sciences and Education (IJHSSE), vol 5, no. 2, pp. 1726. http://dx.doi.org/10.20431/2349-0381.0502003.

Cheung, T., Wong, S. Y., Wong, K. Y., Law, L. Y., Ng, K., Tong, M. T., ... Yip, P. S. F. (2016). Depression, anxiety, and symptoms of stress among baccalaureate nursing students in Hong Kong: A cross-sectional study. International Journal of Environmental Research and Public Health, 13(8), 779.

Datu, J. A. D., \& Valdez, J. P. M. (2012). Exploring Filipino adolescents' conception of happiness. International Journal of Research Studies in Psychology, 1(3), 21-29.

Datu, J. A. D., King, R. B., \& Valdez, J. P. M. (2017). The academic rewards of socially-oriented happiness: Interdependent happiness promotes engagement. Journal of School Psychology, 61, 19-31.

Datu, J. A. D., King, R. B., \& Valdez, J. P. M. (2018). Psychological capital bolsters motivation, engagement, and achievement: Cross-sectional and longitudinal studies. The Journal of Positive Psychology, 13(3), 260-270.

Datu, J. A. D., King, R. B., Valdez, J. P. M., \& Eala, M. S. M. (2018). Grit is connected with weaker depression via meaning in life among Filipino high school students. Youth \& Society. Advance online publication. https://doi.org/10.1177/0044118X18760402.

Datu, J. A. D., \& Valdez, J. P. M. (2016). Psychological capital predicts academic engagement and well-being in Filipino high school students. The Asia-Pacific Education Researcher, 25(3), 399405.

Datu, J. A. D., Valdez, J. P., Cabrera, I. K., \& Salanga, M. G. (2017). Subjective happiness optimizes educational outcomes: Evidence from Filipino high school students. Spanish Journal of Psychology. Advance online publication. doi:10.1017/sjp.2017.55

Dew, R. E., Daniel, S. S., Armstrong, T. D., Goldston, D. B., Triplett, M. F., \& Koenig, H. G. (2008). Religion/spirituality and adolescent psychiatric symptoms: A review. Child Psychiatry and Human Development, 39, 381-398. doi:10.1007/s10578-007-0093-2

Estrada, C. A. M., Lomboy, M. F. T. C., Gregorio, E. R., Amalia, E., Leynes, C. R., Quizon, R. R., \& Kobayashi, J. (2019). Religious education can contribute to adolescent mental health in school settings. International journal of mental health systems, 13(1), 1-6.

Fellmeth, G., Rose-Clarke, K., Zhao, C., Busert, L. K., Zheng, Y., Massazza, A., \& Orcutt, M. (2018). Health impacts of parental migration on left-behind children and adolescents: a systematic review and meta-analysis. The Lancet, 392(10164), 2567-2582.

Fomina, T., Burmistrova-Savenkova, A., \& Morosanova, V. (2020). Self-regulation and psychological well-being in early adolescence: A two-wave longitudinal study. Behavioral sciences (Basel, Switzerland), 10(3), 67. https://doi.org/10.3390/bs10030067

Fu M, Xue Y, Zhou W., \& Yuan T-F (2017). Parental absence predicts suicide ideation through emotional disorders. PLoS ONE 12(12): e0188823.https://doi.org/10.1371/journal. pone.0188823.

Garcia, D., Al Nima, A., \& Kjell, O. N. E. (2014). The effective profiles, psychological well-being, and harmony: Environmental mastery and self-acceptance predict the sense of harmonious life. Perj, 2(e259), 1-2. https://doi.org/10.7717/peerj.259.

Gariepy, G., Elgar, F.J., Sentenac, M., \& Barrington-Leigh, C. (2017). Early-life family income and subjective well-being in adolescents. PLoS ONE 12(7): e0179380. https://doi.org/10.1371/ journal.pone. 0179380 
Inchley, J., \& Currie, D. (2016). Growing up unequal: gender and socioeconomic differences in young people's health and well-being. Health behaviour in school-aged children (HBSC) study: international report from the 2013/2014 survey (No. 7). World Health Organization.

Keizer, R., Helmerhorst, K. O., \& van Rijn-van Gelderen, L. (2019). Perceived quality of the mother-adolescent and father-adolescent attachment relationship and adolescents' selfesteem. Journal of youth and adolescence, 48(6), 1203-1217.

Keyes, C. L. M. (2002). The mental health continuum: From languishing to flourishing in life. Journal of Health and Social Behavior, 43(2), 207-222.

King, R. B. \& Datu, J. A. (2017). Happy classes make happy students: Classmates' well-being predicts individual student wellbeing. Journal of School Psychology, 65, 116-128.

Lampropoulou, A. (2018). Personality, school, and family: What is their role in adolescents' subjective well-being? Journal of adolescence, 67, 12-21.

Lam, T. \& Yeoh, B. (2019). Parental migration and disruptions in everyday life: reactions of leftbehind children in Southeast Asia. Journal of ethnic and migration studies, 45(16), 3085-3104. https://doi.org/10.1080/1369183X.2018.1547022

Lester, L. \& Cross, D. (2015). The relationship between school climate and mental and emotional wellbeing over the transition from primary to secondary school. Psychology of Well-being, 5(1), 9.

Linonge-Fontebo, H. N. \& Rabe, M. (2015). Mothers in Cameroonian prisons: Pregnancy, childbearing, and caring for young children. African Studies, 74(3), 290-309.https://doi.org/10. 1080/00020184.2015.1068000.

Michaelson, V., Pickett, W., Robinson, P., \& Cameron, L. (2015). Participation in church or religious groups and its association with health. Part 2: A Canadian qualitative study. Journal of Religion and Health, 54(3), 1118-1133.

Moretti, M. M., \& Peled, M. (2004). Adolescent-parent attachment: Bonds that support healthy development. Paediatrics \& child health, 9(8), 551-555.

Nalipay, M. J. N., Bernardo, A. B. I. \& Mordeno, I. G. (2016). Social complexity beliefs predict posttraumatic growth in survivors of a natural disaster. Psychological Trauma: Theory, Research, Practice, and Policy, 8, 559-567.

Nalipay, M. J. N., Bernardo, A. B. I., \& Mordeno, I. G. (2017). Posttraumatic growth in survivors of a natural disaster: The role of the social axioms of religiosity, the reward for application, and social cynicism. The Journal of Positive Psychology, 12, 342-353.

Nell, W., \& Rothmann, S. (2018). Hope, religiosity, and subjective well-being. Journal of Psychology in Africa, 28(4), 253-260.

Odgers, C. L. (2015). Income inequality and the developing child: Is it all relative? American Psychologist, 70(8), 722.

Pallant, J. (2020). SPSS survival manual: A step-by-step guide to data analysis using IBM SPSS. Routledge.

Parks, A. C., Della Porta, M. D., Pierce, R. S., Zilca, R., \& Lyubomirsky, S. (2012, May 28). Pursuing happiness in everyday life: The characteristics and behaviors of online happiness seekers. Emotion. Advance online publication. http://dx.doi.org/10.1037/a0028587.

Patalay, P. \& Fitzsimons, E. (2018). Development and predictors of mental ill-health and wellbeing from childhood to adolescence. Soc. Psychiatry Psychiatr. Epidemiol. 53, 1311-1323. https:// doi.org/10.1007/s00127-018-1604-0

Petts, R. J. (2014). Family, religious attendance, and trajectories of psychological well-being among youth. Journal of Family Psychology, 28(6), 759-768.

Ramsay, J. E., Tong, E. M., Chowdhury, A., \& Ho, M. H. R. (2019). Teleological explanation and positive emotion serially mediate the effect of religion on well-being. Journal of personality, 87(3), 676-689.

Ruggeri, K., Garcia-Garzon, E., Maguire, Á., Matz, S., \& Huppert, F. A. (2020). Well-being is more than happiness and life satisfaction: a multidimensional analysis of 21 countries. Health and quality of life outcomes, 18(1), 1-16.

Ryff, C. D. (1989). Happiness is everything, or is it? Explorations on the meaning of psychological well-being. Journal of Personality and Social Psychology, 57(6), 1069-108. doi:10.1037/00223514.57.6.1069 
Ryff, C. D. (2017). Eudaimonic well-being, inequality, and health: Recent findings and future directions. International Review of Economics, 64(2), 159-178.

Ryff, C. D. (2014). Psychological well-being revisited: advances in the science and practice of eudaimonia. Psychotherapy and Psychosomatics, 83(1), 10-28.

Shamsuddin, K., Fadzil, F., Ismail, W. S. W., Shah, S. A., Omar, K., Muhammad, N. A., ... Mahadevan, R. (2013). Correlates of depression, anxiety, and stress among Malaysian university students. Asian Journal of Psychiatry, 6(4), 318-323.

Suleiman, A. K., Ismadi, N. F. I., Choudhry, F. R., Munawar, K., \& Hameed, M. A. (2017). Determinant factors of depression: a survey among university students. Malaysian Journal of Public Health Medicine, 17(3), 97-103.

Sun, X., Chan, D. W., \& Chan, L. (2016). Self-compassion and psychological well-being among adolescents in Hong Kong: Exploring gender differences. Personality and Individual Differences, $101,288-292$.

Teh, C. K., Ngo, C. W., Zulkifli, R. A. Binti, Vellasamy, R., \& Suresh, K. (2015). Depression, anxiety, and stress among undergraduate students: A Cross-sectional study. Open Journal of Epidemiology, 5(4), 260-268.

U.S. Bureau of Labor Statistics (2018) Employment characteristic of families-2017. https://www.bls. gov/news.release/pdf/famee.

U.S. Census Bureau. (2018). Current population survey, annual, social, economic supplement. https://www.childstats.gov/americaschildren19/tables/fam1a.asp

Vandivere, S., Yrausquin, A., Allen, T., Malm, K., \& McKlindon, A. (2012). Children in nonparental care: A review of the literature and analysis of data gaps. Children, 12, 01.

Villavicencio, F. T. \& Bernardo, A. B. I. (2016). Beyond math anxiety: Positive emotions predict mathematics achievement, self-regulation, and self-efficacy. The Asia-Pacific Education Researcher, 25(3), 415-422.

Vishkin, A., Bloom, P. B. N., \& Tamir, M. (2019). Always look on the bright side of life: religiosity, emotion regulation, and well-being in a Jewish and Christian sample. J. Happiness Stud. 20, 427-447. doi: 10.1007/s10902-017-9956-9

\section{Correspondence:}

CECILIA M. SABLAON

chelse2ella@yahoo.com

https://orcid.org/000-0002-9610-5389

DENNIS V. MADRIGAL

dennis_madrigal@yahoo.com

https://orcid.org/0000-0001-5548-2682 